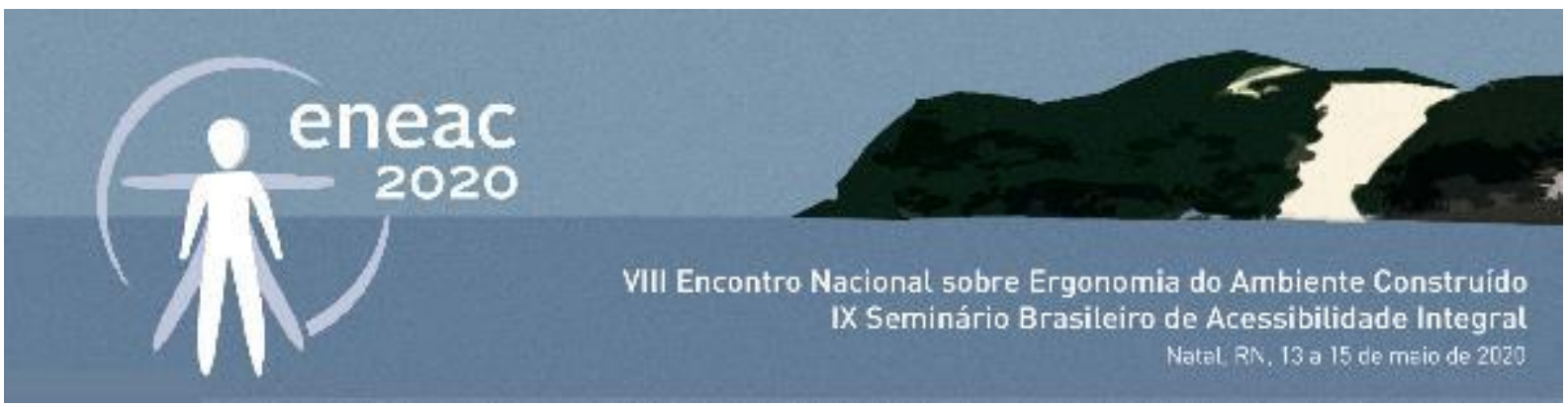

\title{
Aspectos Históricos da Tecnologia Assistiva e o Processo de Reabilitação e Inclusão
}

\section{Historical Aspects of Assistive Technology and the Rehabilitation and Inclusion Process}

\author{
Doutora em Ciências pela Universidade de São Paulo, Professora-adjunta do Departamentod \\ Terapia Ocupacional - Universidade Federal da Paraíba - claudia.galvao@academico.ufpb.br
}

\section{RESUMO}

O acesso aos dispositivos de Tecnologia Assistiva e sua utilização como um recurso para facilitar a execução de uma tarefa cotidiana tem sido parte da rotina e do processo de reabilitação com a disponibilização de novas tecnologias no mercado. Uma breve retrospectiva dos avanços da Tecnologia Assistiva no país é apresentada com uma ênfase relacionada à pessoa com deficiência, quanto às suas condições de acesso e à necessidade de eliminar barreiras encontradas nos diversos ambientes. 0 planejamento e/ou as mudanças determinadas requerem um acompanhamento do processo de aceitação e adaptação do usuário aos recursos ou serviços. O profissional responsável deve compreender as demandas do indivíduo e suas preferências, desde a fase do projeto inicial até a aquisição do equipamento disponível no mercado, confeccionado sob medida ou modificado, para possibilitar o acesso a essa tecnologia ou à prestação de serviços que favoreça o processo de inclusão. A discussão apresentada é parte do conteúdo disparador acerca do papel da Tecnologia Assistiva para a Ergonomia e a Acessibilidade Integral, considerando a potencialidade da área de Arquitetura, Urbanismo e Design no processo dinâmico, com o fim de promover a inclusão em seus diversos aspectos.

PALAVRAS-CHAVE: ENEAC 2020; Tecnologia Assistiva; Pessoas com deficiência; Equipamentos de autoajuda; Terapia ocupacional. 